\title{
Dynamic and Static Characteristic Analysis of the Main Shaft System
}

\author{
Xinyu Wang ${ }^{1, a^{*}}$ \\ ${ }^{1}$ The School of Applied Technology, University of Science and Technology Liaoning, \\ Anshan Liaoning 114000, China \\ a95764301@qq.com
}

Keywords: the dynamic and static characteristic; the main shaft; the spindle offset Abstract. Main shaft system includes a main shaft, bearings and driving medium. The performance of main shaft system has important influence on the machining quality and the productivity of machine tool. It is the important factors that affect job performance. Main shaft supporting structure, support number and support position all affect main shaft system. The impact of these factors on the main shaft system was reflected in aspect of dynamic and static characteristics.

\section{Introduction}

The support distance of the main shaft system is the specific indicators which influence the dynamic and static characteristic of the main shaft system.

The dynamic and static characteristics of the main shaft system include natural frequency, amplitude of the front bearing, cutting ultimate length and deformation. The dynamic and static characteristics are affected by many factors. The main shaft supporting distance is one of the important influencing factors. So choosing the best value for a distance is very important.

The change of the distance has a great influence on the dynamic characteristics of the main shaft. The change of the distance caused the resonant frequency and amplitude changes. They were shown in Fig. 1.

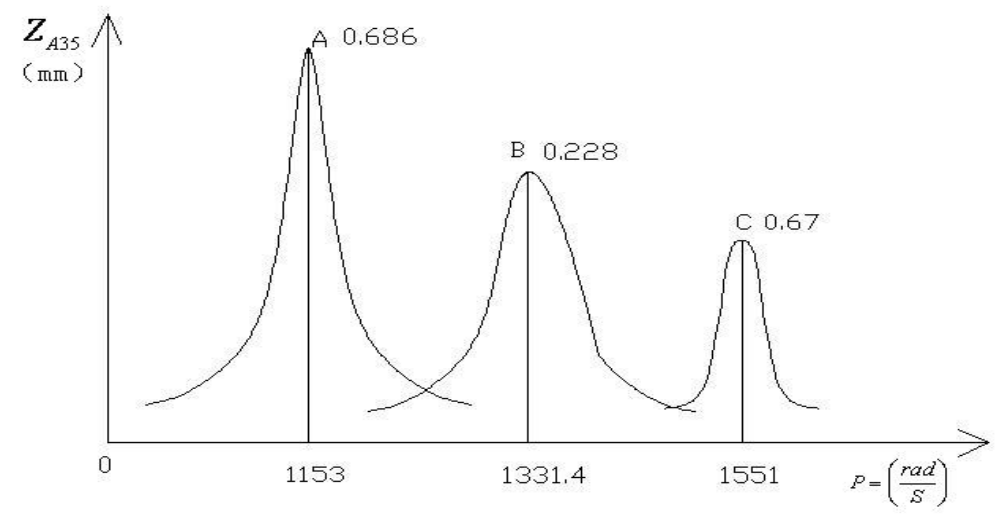

Fig. 1. The change of the distance caused the resonant frequency and amplitude changes

Where: P----- resonant frequency; $\mathrm{Z}_{\mathrm{A} 35^{----}}$the deflection amplitude of the main shaft end point; $\mathbf{A}$, B, C------ the simultaneous vibration of main shaft.

Machine tool spindle worked mostly under irregular alternating stress. When the offset distance changed, force and torque of main shaft system changed too. So the strength of the main shaft system changed also. The change law presented normal distribution. The main shaft offset of C616 changed three times. The main shaft were aroused resonance three times. The amplitude were A, B and C. The curves showed that the inhibition of the first natural frequency of resonance was important. Too large value was caused by the system damping distribution. And it was relevant with supporting distance. 
When the offset distance was best value, the deformation was the minimum, and the amplitude was also the minimum.

\section{The main shaft characteristics analysis influenced by two support structure}

The factors affected the dynamic and static characteristics of the main shaft system had three aspects: the first was the front bearing type, the second was offset, and the third was the load of the bearing.

Theoretical analysis and a large number of experiments showed that the main shaft offset distance affected the natural frequency and the amplitude remarkably. When the main shaft offset was not at the same size, the impact characteristics were shown in Table 1.

Table 1 Performance comparison when the supporting distance is different

\begin{tabular}{ccccc}
\hline $\begin{array}{c}\text { offset distance ( } \\
\text { mm ) }\end{array}$ & $\begin{array}{c}\text { frequency } \\
\mathrm{f}(\mathrm{HZ})\end{array}$ & $\begin{array}{c}\text { amplitude } \\
\mathrm{A}(\mu)\end{array}$ & $\begin{array}{c}\text { grooving } \\
\mathrm{L}_{0}(\mu)\end{array}$ & $\begin{array}{c}\text { Static deformation } \\
\delta(\mu)\end{array}$ \\
\hline B1 650 & 0.93 & 1.78 & 1.01 & 1.23 \\
B2 535 & 0.96 & 1.57 & 1.03 & 1.08 \\
B3 385 & 1.00 & 1.00 & 1.00 & 1.00 \\
\hline
\end{tabular}

Statistics indicated that: The offset distance was the main factor affecting the amplitude.

(1) We selected the offset distance in the range of $385 \mathrm{~mm}-650 \mathrm{~mm}$. When the offset distance was small the frequency and amplitude were also small, and which could make the main shaft to obtain good static and dynamic characteristics. This value was reasonable. In production, we should choose this best value.

(2) When the distance was greater than $520 \mathrm{~mm}$, all the characteristics generally trended poor state. When the ratio of the diameter of the support to the front bearing was greater than 5.4, we must increase the offset length. But increasing the length of the distance would be limited by the structure, and increasing the length of the distance should be ensured to improve the rotation accuracy of the spindle system.

(3) We could not choose too large distance in production. Priority should been given to the value of the best distance value. The front bearing support could not be ignored. Its effect on performance was very significant. The best distance should been selected. The front bearing type must also be used in big profit. For example, the characteristics comparing of the different types of front bearing could be got from Table 2 .

Table 2 Characteristics comparing of the different types of front bearing

\begin{tabular}{|c|c|c|c|c|c|c|c|c|}
\hline \multirow{2}{*}{$\begin{array}{c}\text { front bearing } \\
\text { type }\end{array}$} & \multirow{2}{*}{\multicolumn{2}{|c|}{$\begin{array}{l}\text { bearing configuration } \\
\text { diagram }\end{array}$}} & \multicolumn{4}{|c|}{ performance } & \multirow{2}{*}{ characteristic } & \multirow{2}{*}{ application } \\
\hline & & & $\mathrm{f}$ & $\mathrm{A}$ & $\mathrm{L}_{\mathrm{C}}$ & $\delta$ & & \\
\hline $\begin{array}{c}\text { (5) } \\
\text { C2697120 }\end{array}$ & $\sum$ & 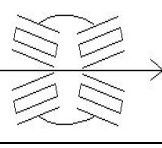 & $\begin{array}{c}1.0 \\
6\end{array}$ & $\begin{array}{c}0.8 \\
3\end{array}$ & $\begin{array}{c}1.1 \\
7\end{array}$ & $\begin{array}{c}1.2 \\
7\end{array}$ & $\begin{array}{l}\text { good dynamic; } \\
\text { static general; } \\
\text { good cutting }\end{array}$ & $\begin{array}{c}\text { general } \\
\text { accuracy } \\
\text { machine tool }\end{array}$ \\
\hline $\begin{array}{c}\text { (4) } \\
\mathrm{C} 2007120\end{array}$ & & $\lesssim$ & $\begin{array}{c}0.0 \\
4\end{array}$ & $\begin{array}{c}1.0 \\
3\end{array}$ & $\begin{array}{c}1.0 \\
9\end{array}$ & $\begin{array}{c}1.7 \\
1\end{array}$ & $\begin{array}{l}\text { bad static; } \\
\text { cutting general }\end{array}$ & $\begin{array}{c}\text { general } \\
\text { accuracy } \\
\text { machine tool }\end{array}$ \\
\hline $\begin{array}{c}\text { (3) } \mathrm{C} 3182120 \\
+ \\
\mathrm{C} 2268120\end{array}$ & $\frac{1}{4 x}$ & 站吾 & $\begin{array}{c}1.0 \\
0\end{array}$ & $\begin{array}{c}1.0 \\
0\end{array}$ & $\begin{array}{c}1.0 \\
0\end{array}$ & $\begin{array}{c}1.0 \\
0\end{array}$ & $\begin{array}{l}\text { good static; } \\
\text { dynamic } \\
\text { general; bad } \\
\text { cutting }\end{array}$ & $\begin{array}{l}\text { precision } \\
\text { machine tool } \\
\text { and high } \\
\text { speed } \\
\text { machine tool }\end{array}$ \\
\hline
\end{tabular}


From Table 2 we could see the following conclusions:

If we adopted double row tapered roller bearings (2697120) dynamic characteristics of the spindle system could be significantly improved. Priority should be given to it. The dynamic characteristics were the same when the bearings were the thrust ball bearings for a machine tool spindle.

If we adopted double row short cylindrical roller bearing (3182120) the static characteristics of the main shaft system had been greatly improved. If we used double row radial thrust ball bearings the static characteristics of the main shaft system had also been greatly improved. You could use these two types of bearings.

Of course if the bearing load was very appropriate the spindle system characteristics were more obvious. Empirical evidenced: if the load was $400 \mathrm{~kg}$ we could get a good natural frequency, the amplitude was also obtained with a better numerical value.

\section{Main shaft characteristics analysis influenced by three support structure}

Three supporting structure is more a support than two support structure. The support structure is auxiliary support. In the three supports there are several different situations, the front and rear support is given priority to, the front and center support is given priority to. Auxiliary support can be the middle support. It can also be a support behind. The different positions have different influence on the characteristics of the spindle system. For example: the three support position of a main shaft was got from Table 3.

Table 3 Three support positions

\begin{tabular}{|c|c|c|c|}
\hline style factor & $\begin{array}{c}\text { auxiliary } \\
\text { support(A) }\end{array}$ & $\begin{array}{c}\text { front and rear support } \\
\text { distance(B) }\end{array}$ & $\begin{array}{c}\text { Front and middle } \\
\text { support distance(C) }\end{array}$ \\
\hline 1 & middle support & 535 & 260 \\
\hline 2 & rear support & 650 & 385 \\
\hline
\end{tabular}

\section{(1) Auxiliary support position A}

Using range analysis and experience we could get that A was the major impact. It also had a greater impact on the cutting groove. The performance comparison of auxiliary support at different positions was shown as the Table 4.

Table 4 Performance comparison of auxiliary support at different positions

\begin{tabular}{llcccc}
\hline \multicolumn{2}{c}{ auxiliary support } & $\mathrm{f}$ & $\mathrm{A}$ & $\mathrm{L}_{\mathrm{C}}$ & $\delta$ \\
\hline $\mathrm{A}_{1}$ & middle support & 1.00 & 1.00 & 1.00 & 1.00 \\
$\mathrm{~A}_{2}$ & rear support & 1.03 & 0.78 & 1.04 & 0.92
\end{tabular}

Parameter displayed that $\mathrm{A}_{2}$ was the best value. The main shaft system had good dynamic and static characteristics if the behind support was used as an auxiliary support. This could improve working performance.

(2) The front and rear support B

The action of the front and rear supports was relatively minor. The performance comparison was shown in Table 5 when the front and rear support were different.

Table 5 Performance comparison when the front and rear support were different

\begin{tabular}{ccccc}
$\begin{array}{c}\text { front and rear support distance } \\
(\mathrm{mm})\end{array}$ & $\mathrm{f}$ & $\mathrm{A}$ & $\mathrm{L}_{\mathrm{C}}$ & $\delta$ \\
\hline $\mathrm{B}_{1} 535$ & 1.00 & 1.00 & 1.00 & 1.00 \\
$\mathrm{~B}_{2} 650$ & 1.01 & 1.11 & 1.04 & 0.98 \\
\hline
\end{tabular}


We could obtain that from table 5 the frequency and the groove were the best when the front and rear support was $650 \mathrm{~mm}$. But the amplitude index was poor. The amplitude index were the best when the front and rear support was $535 \mathrm{~mm}$. But the frequency and the groove were poor.

(3) The front and middle support distance C

The front and middle support distance had a great influence on the dynamic characteristics. It especially played a leading role for cutting groove. The performance comparison was shown in Table 6 when the front and middle support distance were different.

Table 6 Performance comparison when the front and middle support distance were different

\begin{tabular}{ccccc}
\hline $\begin{array}{c}\text { front and middle support distance } \\
(\mathrm{mm})\end{array}$ & $\mathrm{f}$ & $\mathrm{A}$ & $\mathrm{L}_{\mathrm{C}}$ & $\delta$ \\
\hline $\mathrm{C}_{1} 260$ & 1.02 & 0.91 & 1.07 & 0.95 \\
$\mathrm{C}_{2} 385$ & 1.00 & 1.00 & 1.00 & 1.00 \\
\hline
\end{tabular}

We could obtain that from Table 6 when the front and middle support was $260 \mathrm{~mm}$ the dynamic characteristics of the spindle system were the best values. If a small value was selected in the range $(260 \mathrm{~mm}-385 \mathrm{~mm})$ of the front and middle support distance, the better dynamic and static characteristics could been obtained.

\section{Summary}

(1) The support distance of the two support structure was an important factor affecting the amplitude and natural frequency. It had certain effect on other indexes. If the support distance was within the range of $385 \mathrm{~mm}-650 \mathrm{~mm}$ a smaller value was the best value. At this time the spindle system could have good dynamic and static characteristics, see Table 1. Front bearing was double row roller cone bearing, the model was 2697120 . Rear bearing was single row radial roller cone bearing. Load was $400 \mathrm{~kg}$ and which were controlled with spring. Which before and after bearing spacing were not greater than $20 \mathrm{~mm}$ was a better solution.

(2) Auxiliary support position was one of the important factors which affect the spindle system dynamic and static characteristics. When the auxiliary support was the support behind the main shaft system had good characteristics. At this point, the former and middle support was the main support. And in this scheme, we should pay attention to the influence of the size of the distance to the dynamic characteristics. Therefore, if the selection was within the range of $260 \mathrm{~mm}-385 \mathrm{~mm}$, the smaller front and middle distance should been selected. Like this, we could get better dynamic and static characteristics.

(3) When we designed the main shaft support type, we should give priority to the use of the two supporting structure scheme. When the structural arrangement was difficult, we used the three support type. When using the three support scheme we'd better choose the way of support that the former and middle was tight and the behind was loose.

\section{References}

[1] Chuanjun Li, NC machine tools and programming teaching material, Peking University press, 2009.10

[2] Editorial Committee of Mechanical Engineering Handbook, Mechanical Engineering Manual, 1989.3

[3] Dai Shu, Metal cutting machine tool, Machinery Industry Press, 2004.1 